\title{
Insiders and outsiders and a hermeneutic of resonance
}

\begin{tabular}{|c|c|}
\hline \multicolumn{2}{|c|}{$\begin{array}{l}\text { Author: } \\
\text { Glenna S. Jackson }{ }^{1,2}\end{array}$} \\
\hline \multicolumn{2}{|c|}{$\begin{array}{l}\text { Affiliations: } \\
{ }^{1} \text { Department of Religion } \\
\text { Philosophy, Otterbein } \\
\text { University, Westerville, } \\
\text { United States }\end{array}$} \\
\hline \multicolumn{2}{|c|}{$\begin{array}{l}{ }^{2} \text { Department of New } \\
\text { Testament Studies, Faculty of } \\
\text { Theology, University of } \\
\text { Pretoria, South Africa }\end{array}$} \\
\hline \multicolumn{2}{|c|}{$\begin{array}{l}\text { Research Project } \\
\text { Registration: } \\
\text { Project Leader: A.G. van } \\
\text { Aarde (D } \\
\text { Project Number: } 2334682\end{array}$} \\
\hline \multicolumn{2}{|c|}{$\begin{array}{l}\text { Description: } \\
\text { Prof. Dr Glenna Jackson is } \\
\text { participating in the research } \\
\text { project, 'Biblical Theology } \\
\text { and Hermeneutics', directed } \\
\text { by Prof. Dr Andries G. van } \\
\text { Aarde, Post Retirement } \\
\text { Professor in the Dean's Office } \\
\text { of the Faculty of Theology of } \\
\text { the University of Pretoria. }\end{array}$} \\
\hline \multicolumn{2}{|c|}{$\begin{array}{l}\text { Corresponding author: } \\
\text { Glenna Jackson, } \\
\text { Gjackson@otterbein.edu }\end{array}$} \\
\hline \multicolumn{2}{|c|}{$\begin{array}{l}\text { Dates: } \\
\text { Received: } 28 \text { Apr. } 2017 \\
\text { Accepted: } 04 \text { June } 2017 \\
\text { Published: } 26 \text { July } 2017\end{array}$} \\
\hline \multicolumn{2}{|c|}{$\begin{array}{l}\text { How to cite this article: } \\
\text { Jackson, G.S., 2017, 'Insiders } \\
\text { and outsiders and a } \\
\text { hermeneutic of resonance', } \\
\text { HTS Teologiese Studies/ } \\
\text { Theological Studies 73(4), } \\
\text { a4616. https://doi. } \\
\text { org/10.4102/hts.v73i4.4616 }\end{array}$} \\
\hline \multicolumn{2}{|c|}{$\begin{array}{l}\text { Copyright: } \\
\text { (c) 2017. The Authors } \\
\text { Licensee: AOSIS. This } \\
\text { is licensed under the } \\
\text { Creative Commons } \\
\text { Attribution License. }\end{array}$} \\
\hline \multirow{2}{*}{ 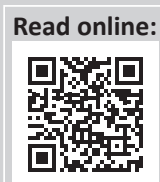 } & \\
\hline & $\begin{array}{l}\text { Scan this QR } \\
\text { code with your } \\
\text { smart phone or } \\
\text { mobile device } \\
\text { to read online. }\end{array}$ \\
\hline
\end{tabular}

In this article, the author once again reflected on her personal and existential experience of frequent visits to African countries as well as to Israel-Palestine. The article focuses on the issues of outsiders becoming effective allies to the cultures they are visiting, teaching and researching by listening to other understandings and interpretations of biblical texts, Jesus' parables specifically. It is an appropriate tribute to Yolanda Dreyer because of Prof. Dreyer's involvement and significant contributions in issues of social justice, both academically and experientially.

\section{Introduction: Parable parallels from Africa}

Be on guard! Stay alert! For you never know what time it is. It's like a person who takes a trip and puts slaves in charge, each with a task, and enjoins the doorkeeper to be alert. Therefore, stay alert! For you never know when the landlord returns, maybe at dusk, or at midnight, or when the rooster crows, or maybe early in the morning. He may return suddenly and find you asleep. What I'm telling you, I say to everyone: Stay alert! (Mk 13:33-37, SV)

According to the Jesus Seminar, this Markan text is not regarded as a historical-Jesus saying because of its seeming apocalyptic tenor, but there is the thought that Jesus himself may have used the image of a returning landlord (Jesus Seminar 1993:114-115) ${ }^{1}$ and the role of the door or gatekeeper. The role of a gatekeeper is to keep outsiders out and safeguard insiders (and their belongings) who are in. ${ }^{2}$ For example, in the small African country of Malawi, there are road stops every few miles on the one and only major highway as well as on some of the secondary roads. And, one doesn't necessarily know where the guards will set up. It may be in one place one day and a few kilometres down the road the next. In any case, one of my students, Corinne, was doing her homestay in the northern region of Malawi, the most poverty-stricken part of the country. Her homestay father owned a small kiosk on the road where persons who were stopped at the guard station or roadblock in the same vicinity might take the time to buy a treat, Coca-Cola or some other small miscellaneous item. In the meantime, the police guards had befriended Corinne while she was working the kiosk and, one day, asked her if she'd like to be the one to let people pass - or not pass - through the roadblock. That is, she could control the pulley that lifted the gate for trucks, cars, bikers and pedestrians to pass through. As it happens, I was on the road with two faculty colleagues, our Malawi host Justice and our driver Dennis, while students were with their homestay families; as the four of us approached this particular roadblock in our coaster [bus], Corinne noticed us from a distance and couldn't wait for our surprise to see that she was the gatekeeper and it would be she who could let us through - or not. She gleefully made us sit for a moment, and as she finally operated the pulley to raise the gate, everyone - she, the five of us, the guards, Corinne's homestay father and his customers - were laughing uproariously at the situation. In the hierarchical world of northern Malawi, it was the student who had unexpected and immediate control over her professors and supervisors, not the usual other way around! Dennis exclaimed, 'Corinne - that girl is welcome to stay in Malawi!' Everyone who witnessed this comedy truly enjoyed the change in the balance of power! And she, as she related to us later on that evening, enjoyed the status as insider with the Malawians and the gatekeepers, temporary though it was.

Because this story involved a student from my university in the United States, it seems reasonable for me to tell the story and, indeed, probably no one would question my regaling it. But, let us try another parable and story, one of my favourites because it is a specific example of the profundity of a normal day's experience in one part of the world that is so completely different from my own:

1.In terms of historicity, John P. Meier somewhat ambiguously states that the whole of Mark 13 is a 'composite, made up of various
sayings and blocks of sayings whose common eschatological theme helped draw them together over time, with Mark supplying the final form and framework' (Meier 1994:344).

2.For a fun read about insider and outsider experiences, see Jackson (2011:11-16). 
A man had a fig tree growing in his vineyard; he came looking for fruit on it but didn't find any. So he said to the vinekeeper, 'See here, for three years in a row I have come looking for fruit on this tree, and haven't found any. Cut it down. Why should it suck the nutrients out of the soil?' In response he says to him, 'Let it stand, sir, one more year, until I get a chance to dig around it and work in some manure. Maybe it will produce next year; but if it doesn't, we can go ahead and cut it down'. (Lk 13:6-9, SV)

This parable is usually understood in the context of repentance. Meier, for example, explains:

The barren fig tree, which has been visited by its owner for three years in a row, is nevertheless granted a reprieve of one more year, during which time great care will be taken with it, in the hope that it will produce fruit and so forestall its destruction. In effect, the parable announces the short time of grace still left for the audience of Jesus; the parable is an urgent call to repentance, in the hope that the audience may yet escape judgment and punishment. (Meier 1994:985)

However, Meier maintains that this 'story has its origin in Christian teaching' (Meier 1994:986), that is, not from the historical Jesus. This time, the Jesus Seminar wants it both ways: while common lore (both Hebrew scriptures and rabbinic literature) uses the 'barren fig tree as a sign of curse or judgment', and, therefore, not original to Jesus:

its ending is contrary to what one would expect from a tree so hopelessly barren, and it lacks a specific application. An exaggerated hope of some sort is implicit, but not specified. A majority of the Fellows found these features sufficient to warrant a pink designation [probably historical]. (Jesus Seminar 1993:345)

But Ntahoturi from Burundi, one of my students at Africa University in Mutare, Zimbabwe, understood the parable much more literally. This is his parallel story from a cultural perspective:

The Kudzunga family rejoiced when their elder son got married. Everyone in the family looked forward to the success of this couple (Tatenda and Tendai). After the wedding day the aunts expected their sister in-law to have conceived. Two months, five months, a year, there were no signs of pregnancy. One of the aunts was bold enough, she went and asked her brother, Tatenda. She said, 'Tatenda, what is going on between you and Tendai? It is high time that you should have a child'. Tatenda calmly responded, 'Auntie, give us one more chance; we will do it, just allow us to look into the issue'. The auntie finally said, 'If your wife is barren you better divorce her and marry somebody who is productive or you better marry a second wife who will give you children'.

Sophirina, also a student at Africa University, has a similar understanding of the parable from her Zimbabwean perspective:

'Barrenness in my context is associated with women. Fig trees are wild trees. Farmers do not grow fig trees. The trees just grow by themselves in the bush. If a woman is married she is expected to bear children. There is this concept that those with many children are the richest people. Every woman is greatly honored by the society if she bears fruits. If she fails to do so she is regarded a cursed woman. For that reason there are two options: the inlaws ask their son to divorce and marry another woman whose womb is prepared to bear fruit. Or, if the woman is to remain with her husband's family, her parents will be asked to provide a wife to the husband so that she bears offspring on behalf of the aunt or sister. Barrenness in my society is not tolerated. The main purpose of marriage is to produce children for the family. As soon as the two get married, results have to be shown. Without procreation a woman is regarded as useless within the society.'

The parable made perfect sense to both of them!

And Emmanuel, one of my students at the Presbyterian Theological Seminary in Kumba, Cameroon, also does not connect repentance to the story and has the following to say about a tree that was in danger of being cut down:

'If one has to understand the Parable of the Barren Fig Tree in my native community, it will be very fitting to consider why cola nut trees, whether fruitful or barren, should not be cut down. In my community, so much value is attached to the cola nut tree. Every courtyard and surrounding has cola nut trees of various sizes and ages. Some of these are as old as the compound, or as old as members of the family. The story is told of an identification officer who came to our locality to establish identity cards for the inhabitants. When the officer sought to know the age of the family head [who did not know his own birth date], he was shown a cola nut tree that was about the man's age. So he was told that if he could estimate the age of the tree he could guess how old the family head was.'

That sounds simple enough - cut down the tree, count the inner rings and determine the age of the village elder. As Emmanuel read his parable in class, I wasn't sure if I understood what he was saying; Ineeded further explanation. As his student colleagues grinned at the opportunity to teach me their culture, Emmanuel explained several aspects of what the rest of the class fully understood:

One of the traditions in Cameroon is that, like many African and Middle Eastern countries, a tree is planted in a newborn baby's honour. In some cultures, an additional tree is planted for every succeeding birthday. In Israel-Palestine, for example, by the time a son becomes of marriageable age, his grove of trees will provide enough wood to build a house.

Identification officers are not always looked upon kindly - they are sometimes viewed as interlopers working on behalf of a government that can be regarded as ruthless and/or immoral. To need the exact age of the chief or family head, who did not know the year he was born, seemed unnecessary to the community.

And what we could not possibly know from a western perspective is that the 'cola' nut trees are considered to be sacred, no one cuts them down without proper rituals from a traditional priest. Since the fruit of the tree 'brings life', the tree itself must be conserved for the sustainability of the community. Indeed, if a cola nut tree is cut down for some important reason such as the construction of a house or road, mourning rituals are demanded - as though it were a funeral.

And so the family dared the officer to cut down the tree to determine the age of their chief. Just like the parables of Jesus, we don't know the ending - did the identification officer cut down the tree to fulfil his obligation and, at the same time, risk the dangers inherent in cutting down a sacred tree? 
Did the officer walk away, thereby admitting defeat to the community as well as to his boss (Jackson 2013a:238-239)? The pacifist resistance in this parable is remarkable!

While it was noted that neither the Jesus Seminar nor John Meier understand this pericope to be authentically Jesus, that is, it is a figment of the Christian community's imagination; but, it is still important to consider why the parable was included in the gospel writing. I think the major problem with exegetes arguing for its authenticity, but at the same time, the missed mark on the pericope's use as a prophetic cast upon the Temple's longevity, is the major mistake. The parable should, rather, be viewed as a description in which the listeners can supply their own endings and applications, just as Sophirina, Ntahoturi and Emmanuel did. They can relate to the life of a tree as metaphorical for the human condition or as its importance to the community, and not always because of the fruit it bears.

In order to emphasise the contextual as well as my outsider status, I rehearse a Cameroonian parable from Julius, also a student at the Seminary:

'Pa Lukas Nde told his friends that he had killed a cow and ate for 20 years and is still eating it. One of the friends was anxious about it and so he gathered some money, bought and killed a cow and kept it in the [cellar]. Two weeks later, the house was full of bad stinking. He rushed back to his friends and asked, "Pa Lukas, you told me you killed a cow and ate for 20 years and that you are still eating. What is wrong that mine is only two weeks dead and is already smelling?" Pa Lukas laughed and told him, "My friend, what I did was that when I killed the cow I called my friends, neighbors, and relatives and shared with them and each time they see me, they equally share what they have with $[\mathrm{me}]$. This has made me to continue to enjoy the cow I killed so many years back even though I have no cow now".'

I love this story. ${ }^{3}$

Another example of an experience to which I am not accustomed includes one of my visits to Zimbabwe, where I worshiped at Hilltop United Methodist Church on Palm Sunday. Hilltop is located in the oldest, poorest part of the city of Mutare. More than 2,000 worshipers were gathered in a relatively small church sanctuary where probably at least one-third of the people are dying of malaria, HIV-related diseases and schistosomiasis. That fact did not keep a single one of them from waving palm branches, singing joyously and proclaiming the gospel message. And what was the gospel message on that day? That if Jesus were a Mozambican who travelled over the Eastern Highland Mountains into Zimbabwe, he would see his people and know their needs; that is, that they needed to be freed of political and economic oppression. And because of that, the Zimbabweans would greet him with palm branches, dancing and singing. That sermon on a pre-election Sunday was not just powerful, but probably the only time that Palm Sunday has ever made any

3.For these and other stories from The Presbyterian Theological Seminary of Cameroon, see Jackson (2013a:238-252). I am indebted to Prof. Ernest Van Eck, The University of Pretoria, who invited me to share teaching responsibilities at the University of Pretoria, who invited me to share teaching responsibilities at the
Seminary in February 2012 and also to Rev. Dr, Mbengu David Nyiawung who yielded his class to us. actual sense to me. Samuel Dzobo, the pastor of the church, was arrested for that sermon and spent several days in prison without anyone, even his family, knowing what happened to him. Only because one of the guards was a member of his church was he released.

\section{The question}

Lest the crux of the matter gets lost, the question must be asked: who gets to tell the stories when they do not originate from one's own culture and context? I've been doing parable parallels research for more than 16 years; I have published articles and book chapters on the topic and they have been received in both indigenous populations and in my own worlds where different understandings can be surprising, but nonetheless, appreciated. ${ }^{4}$ But, how does someone like me who is an outsider to all African cultures move forward with the information and insights I have gained without objectifying the very ones from whom I've received the stories, understandings and ideas? As a white, female feminist Westerner, is it even possible to engage as an effective ally?

\section{An answer from bell hooks ${ }^{5}$}

One of the leading proponents of the vibrancy of diverse communities that can sustain hope and include justice as the core foundation is the noted scholar, bell hooks. Hooks (2003) writes:

When black people/ people of color fully embrace the reality that white people who choose to do so can be anti-racist to the core of their being then we draw these folks to us. [They] make mistakes ... they [may] buy into race privilege ... they [may] enact in daily life racial domination ... [because this can] always happen on an unconscious level. What it does mean is that when they make a mistake they are able to face it and make needed repair. (p. 61)

Ten years later, hooks lists elements of successful boundary crossing, both in the experiential and in writing. Hooks (2013) first notes that:

While the theory [of the positive politics of difference in the 1970's] was all about border crossing, there was little talk about actual practice, of what makes bonding possible across race, class, gender, and diverse politics ... We write more about theory than we do about practice. (pp. 143-144)

Interestingly, I love the actual practice of the experiential; it's the questions of what and how to articulate the experience that befuddle me. Nonetheless, hooks' process of learning and connecting across difference includes active listening, eradicating assumptions, curiosity as in 'radical openness', humour and laughing, ${ }^{6}$ mutuality and partnership, confidence in strategies of resistance [to injustice and domination], compassion and peacemaking, forgiveness and critical feedback (Hooks 2013:148-151). Ultimately, it is all about 'fullon engagement with the practice of love' (Hooks 2013:194).

4.For example, see Jackson (2004a:online; 2004c:239-247; 2005:300-302; 2013b:109134; 2014:online).

5.bell hooks is the scholar's professional name and not capitalised.

6.Also, see hooks' chapter on the importance of 'Crying Time' (2010:77-83) as well as the other two volumes in the trilogy $(1994,2003)$. 


\section{An answer from Mpalale village}

In his collaborative work on performing the gospel, Richard A. Horsley rehearses Werner Kelber's work on orality and literacy:

Kelber was the first to recognize the import of pioneering research by classics scholars who noted not only the oral communication environment of antiquity but also the difference between oral performance and written text as understood according to the assumptions of modern print culture. This led him to challenge the established and deeply ingrained assumptions and methods of form criticism, which treated the oral tradition of the sayings of Jesus as if they were artifacts in print. Mediating the research of the pioneering scholars on orality in other, related fields, he explained, for those with ears to hear, how oral tradition could be understood more appropriately. (Horsley, Draper \& Foley 2006:ix)

What I have been trying to stress for years now is that we as biblical scholars have inherited the written texts, finally gotten outside our disciplinary shells and used methods on performance and orality from other fields, and then, it seems to me, stopped there without taking the next step to see how the texts, memories and storytelling continue to live on in many cultures today and, I'm arguing, this is exactly where we will find the most insights into authorial intent or the entire Historical-Critical Method, at least form and redaction criticisms and a bit of source criticism. And, here's the irony - the experiential is often, if not usually, quite by accident. And, good accidents happen if one has those ears to hear as well as eyes to see. Indeed, it was quite accidental that I arrived in Mpalale Village 8 years ago and have returned at least once every year since.

But there are many ethical issues that surface in this kind of research because it can easily slip into an objectification of the other, specifically the poor or disenfranchised. How, for example, do I talk about, write about or show pictures of Mpalale Village in Malawi to my own communities without immediately objectifying them? Our involvement with this topic is a complex one methodologically, historically, contextually, intellectually and even emotionally, to which we must be committed to respect, value and honour. In my previous discussion of bell hooks' theories of integration and mutuality, there is a sense that all are present and participating with the possibilities of being on equal footing. In this case, $I^{\prime} m$ in and out - in the village once or twice a year, out most of the time, and even when I'm present, I'm actually out.

\section{Here's why}

The catchment population of Mpalale Village is about three hundred people in the rural Central Region of Malawi. The village is isolated and economically poor. It is a Muslim community with an oral language that is unique to them only and it is not in written form. Indeed, my brilliant friend, Nyathipa, learned their language when young pregnant women, who anticipated a difficult delivery, walked the difficult terrain to her hospital in the mountain community of Nkhoma rather than deliver their babies at home. Their language is Choyao, whose original roots are Arabic, but now mixed in with several African mother tongues. A few people in the village speak Chechewe and Tumbuka, the primary mother tongues in Malawi, but most speak only Choyao. As the population of Malawi, according to some sources, is $25 \%$ Muslim, I asked Nyathipa and Justice if they could help to set up interviews when I had a grant to study the spectrum of statuses and roles of women in African Islam. I immediately found a place and culture that was at once simple and complex. Upon my return home from Mpalale the first time, I was curious what I would find out about Malawian villages if I Googled it. This is what popped up:

Perhaps the most unique aspect of Malawi life is the life of the village. The nation remains, in many respects, as it has been for hundreds of years and nothing in its vision reflects this view of the past quite as pronounced as the villages. They are everywhere. Some number only five or ten homes, and the residents are a single family unit. Other villages number into the hundreds of homes and hold not only a single family unit and its extended family, but a number of other families who have chosen this area in which to live. ${ }^{7}$

And this is Mpalale Village! Indeed it is a village large enough for four chiefs - and one of them is a female! So much for stereotypes about villages, Islam and the role of women. To continue the website:

The mud hut, thatched roof villages with their bamboo grain bins, cattle and goats milling around the front door, and children playing happily with other village children are common sites throughout the countryside. One look at a village and the visitor will conclude he or she is looking backward in time by maybe 500 or 1000 years. [I argue that we can glean understanding of at least 2000 years ago, e.g., New Testament times.] The village family tills a small plot of vegetables and maize corn for their own use. They have almost no possessions, and a view inside the hut may reflect only one or two chairs and a single table. The family quarters contain bamboo mats for sleeping, a few ragged blankets to ward off cold nights, and only one or two changes of clothing. The kitchen contains only a single pot and one or two pans for cooking. Nsima (a cornmeal [or cassava] type mix) is the main portion of food taken at every meal, and when times are good a few greens, a few potatoes, and a tomato or two may be added to the diet. It is impossible to know and feel the heartbeat of Malawi until you have spent time in the villages getting to know the heart and soul of the people of this isolated, ancient region of the world. ${ }^{8}$

I could not agree more and I can never wait to return each year!

Upon arrival in Mpalale, we listen to stories and songs and watch their dancing. The narrative in any of those forms constitutes stories of both their heritage and contemporary social mores. While their stories are derived from their own histories, cultures and contexts, they are also reminiscent of gospel times and topics. For example, reliance on the natural world is often the focal point of a story, song or dance. As a matter of fact, Jesus assures his listeners that it is all about

7.http://www.malawiproject.org/about-malawi/geography/districts-cities-villages/ villages

8.Ibid 
trusting God's domain and employs birds, lilies, sparrows, grass and crows as examples of dependence. And, of course, one should ask, seek and knock on the door of a friend (Lk 11:5-10) when one is in need.

Fidon R. Mwombeki, from Tanzania, categorises five different ways that the Bible is used in Africa: (1) the Bible is seen as a symbol of God's presence and protection; for example, Bibles are placed under pillows, in suitcases, in new houses and in coffins. (2) The Bible is read for practical utilisation, for example, giving comfort, instruction, exhortation and even condemnation. (3) The Bible does not always have to be understood rationally: The biblical reading is appropriated spiritually, emotionally and mystically. The historical setting of a text is not significant, and even less the identity of its author. African spiritualism supersedes intelligibility. Most often, the Bible is appropriated worshipfully, by heart, not necessarily by mind. (4) Some settings do demand intelligibility. His examples include a 7-year-old boy, a firstborn child, asking why an angel from God would slaughter the firstborn child of every Egyptian family; defending monogamy in the light of Abraham, David, Solomon, Elkanah and many others; a young intellectual asking why Africans identify with Israel when they should be identifying with Egyptians, Jebusites, Philistines and other peoples who were wiped out and driven out of their lands to give way to the migrating Jews. And, (5) there is strong affinity between the religious and cultural context of the Bible and that of contemporary Africa. Mwombeki's examples and my own include men going out to fish for that day's breakfast and women grinding maize or cassava for the day's meal; sifting and winnowing the grain that might be available; small boys catching mice or birds and roasting them on sticks to eat and sell; beggars and prostitutes in the streets; women carrying babies on their backs and baskets on their heads - and phones in their ears; children carrying tables and chairs back and forth on their heads for school; many, many young men singing in the back of a small pickup truck. The first time I rollerbladed on a country road near Africa University, a young mother almost lost the basket off the top of her head and about 25 young men in the back of a truck stood up and nearly toppled it over as they tried to get a better look - it had not occurred to me that they would not be accustomed to a white woman on wheels. There is light from oil and paraffin lamps on the roads at night that not only provides heat and light but also constitutes a language unto itself for the truck drivers on the road. There is pottery being sculpted or baked in the oven; exclusion of women and children in counts and censuses; a wife's complaints about the other four wives of her husband; a daughter retelling the story of being used as a scapegoat and beaten by her father's first wife because she was the daughter of the third wife; neighbours going to ask for bread to feed an unexpected guest in the middle of the night. I have been that unexpected guest on numerous occasions. There are free 'all-you-can-eat' weddings for all relatives and friends; demon-possessed men, women and children (including one of my travelling companion's epileptic teenaged brothers who died within a year after I met him); a completely bent-over woman who stood up tall and danced the 'old-fashioned' way with her feet moving unbelievably fast when the music began in worship. And when the music ended, she went back to her head-to-feet posture (Cf. Lk 13:10-17). There is strong affinity in social arrangements between African and biblical cultures such as lineage, age-grouping, the value of royalty, birthrights and inheritance laws, the value of the elderly and emotional attachment to ancestral lands (Jackson 2008:7-8; Mwombeki 2001:121-128). In the case of Malawi's ancestral lands, there is an amazing irony: a gorgeous beach-front property that would be worth millions of dollars in California and it houses the poorest of the poor in Malawi.

And so, Mwombeki's two challenges must be included in our discussion. The first is that as a trained reader or theologian, one must work through what has been called the 'hermeneutic of resonance' - to identify the resonance of the biblical text with the theology of the church as well as with the situation of the readers. The situations vary, and each one must be taken seriously into account. The second challenge is to face African realities. Unless one is in Africa, in the banana groves and the desert places, the stinking refugee camps, the crowded town neighbourhoods without proper sanitation, and the hospitals without medicine, one cannot really appreciate how complicated reading the Bible is in such situations - and yet, how real (Mwombeki 2001:127-128) (in the case of Mpalale Village, I would also include the Q'ran).

In other words, we must engage in the experiential. We must actively listen; avoid stereotypes and assumptions; be courteously curious in order to be radically open; laugh; establish partnerships; be courageous and outspoken about economic, political and religious injustices; be compassionate and makers of peace; forgive; and be open to critical evaluations. ${ }^{9}$ Musa W. Dube (1998), from Botswana, adds this:

Unless our critical practice [of biblical studies] takes deliberate measures to understand the mechanisms of past and present imperialisms - to understand the marriage of imperialism with issues of gender, race, class, religion, and sexual orientation even the most liberationist of discourses will end up reinscribing the structures of violence and exploitation. Such travels should move us from an exclusive focus on one historical period, the fortress of the early church, to a concern for the many other histories of the Christian church; from one religious tradition to the other religious traditions of the world; from an approach that is text-oriented to an approach that makes room for symbols, ritual, art, songs, drama, and poetry. Such travels should also move us not only to read and listen to old stories but also to create new stories, as well as to keep the focus on the aims of our critical practice. (p. 243)

\section{Effective Allies}

I have formed partnerships with the residents of Mpalale Village. Indeed, on my very first visit, as we neared the end of a day of storytelling and getting to know one another, the one teacher in the village stood and demanded, 'We're helping you with your research, what are you going to do for us?' I was thrilled with the question because it meant that she was 9.This is Hooks' list. See above. 
willing to look at us as mutually effective allies. So, I responded with, 'What would you like for me to do?' The short answer is that the women of the village needed books that would enable the lone teacher to instruct the women of the village in the Chechewe language, the official mother tongue of Malawi, and, of course, they would in turn teach their children. They also needed a water vessel for wudu [partial ablution]. The men of the village were able to wash in water just outside the mosque, but the women had to wash in the fields where the water pumps were and they often missed prayers. Funds to put a waterproof roof on the mosque as well as carpet for the women's and children's prayer room were also raised.

\section{More parable parallels from Africa and Israel-Palestine}

I am writing this article while on sabbatical in Israel-Palestine. I had been here once before, in 1999, and my recollection is that I was on and off a bus for nearly 10 days, learning a lot about Constantine's mother's churches and where and why she had them built, but not much about ordinary people. This time has been experiential because my husband and I are completely on our own. ${ }^{10}$ These final stories correlate with the Parable of the Good Samaritan (Lk 10:30-35) in dangerous and egregious ways in today's world. The first is Ntahoturi's example from Burundi:

\begin{abstract}
In $1995,^{11}$ I was shopping in the suburb of Bujumbura when I heard gun fire nearby. Two soldiers were shot dead. The rebels were around. In a confused situation, I ran away in the hills. I was not alone. When we began to climb the hill, one mother realized that her five-year-old son was not with her. She was so disturbed. She decided to go back to look for him. We tried to persuade her not to go back. She refused. 'I have to go to look for my son; if I am to die today, there is no option', she said. When she was moving around, the child saw his mother very far away. He was in rebels' hands. He started crying. The rebels suddenly saw the mother and called her to come and take the child. First, she was afraid, but she got courage and she approached them and took the child.
\end{abstract}

And so, according to Ntahoturi, one should identify with the victim rather than with the so-called Good Samaritan because help comes from the most unexpected source, in this case, a soldier from the enemy tribe.

Lo and behold, a similar event occurred to us just the other night in Israel-Palestine and this is my journal entry: We met good friends and colleagues from Finland in the Old City [of Jerusalem] to go on their tour bus to Beit Jalla for dinner at their group's hotel. The city of Beit Jalla borders the city of Bethlehem; both are constituent parts of the Palestinian Territories. Because it is not easy to get a taxi directly from a Palestinian Territory through Jerusalem and to another Palestinian Territory [East Jerusalem where we live], their Israeli tour guide offered to take us back to St. George's College

\section{Thanks to St. George's College for providing housing for us in East Jerusalem.}

11.The same genocide continues in Burundi, even though this story is more than 25 years old, but is rarely reported in international news. because being a tour guide gives her some leeway in both Israel and Palestine. So we are headed down a steep hill with her, sharp curve ahead of us and sharp curve behind us, when she hits a very large pothole and we can hear the air going out of the front two tyres. Plus her spare is not inflated, so she now has a total of three flat tyres. She pulled off to the side of the road in very busy two-way traffic. She was a bit flummoxed and because we did not understand all the cultural mores, we were sparse on suggestions and could not offer any real suggestions, although she assured us that our company was valuable! We found out later that she tried to take a shortcut and was on a road she did not belong and was fearful to call anyone. Anyway, we sat for about an hour when a young man stopped to help. She barely rolls her window down to talk with him because she knows that he is a Palestinian. They speak Arabic (she speaks fluent English, Finnish, Arabic and Hebrew) and he tells her that he is a policeman with the Palestinian police force and would be happy to help get someone to get Gary and me home plus do something about her car. He even told her that just last week his wife had a similar experience with a flat tyre and had waited a lengthy amount of time before someone stopped to help. He was so grateful that someone had finally stopped to help her that he had vowed never to simply pass by someone who was in trouble on the road. But our driver told him she did not want his help. OK. She refuses! Now what? We wait another half hour and the Palestinian bus driver with whom she has been working all week comes down the hill to help. At the same time another young man pulls up to see what's going on and long story short, the Palestinian bus driver tells this Jewish young man who turns out to be an engineer, born and raised in Jerusalem, about these two Americans who need to get to East Jerusalem and so if he could take care of us, he would help the woman with the flat tyres. Agreed. So we get into the car with him - what a delight. He drove us around parts of Jerusalem that we had not seen yet, including Netanyahu's home, and then when he took us to East Jerusalem, we gave him a tour because he had never been there in spite of being a Jerusalemite! I, of course, was reminded of the story of the Good Samaritan - from whom are you willing to take help? Surely, the Jewish tour guide was not going to take help from a Palestinian stranger, but the Palestinian bus driver was willing to take help from the Jewish stranger and because we were just along for the ride, we did not care who helped. Strange world we live in. I was reminded of my last sabbatical when my Batswana hosts and I were stuck with a broken-down car in the Kalahari Dessert in the middle of elephant territory. It took Mabambe's cousin almost $4 \mathrm{~h}$ to reach us with his tow truck and then, of course, $4 \mathrm{~h}$ for us to get to his house for the remainder of the 'night' - but everyone was laughing and having a good time with the unexpected occasion to see one another!

\section{Conclusion}

Many educators argue that our western societies have lost the concept of imagination. Whether one agrees or disagrees, it is important to think about stories and parables of any kind in an oral context and ponder a dynamic that is not made 
static as a result of being written down. When I am in Mpalale Village in Malawi, for example, I am reminded constantly of that kind of energy and movement. Indeed, one of the thrills of my travels to Africa is that of being able to imagine and fantasise, as a New Testament scholar, what 1st-century agrarian cultures and economic and political times may have been like and how stories may have been transmitted. It is my contention that contemporary rural African life may reflect many aspects of 1st-century Galilean rural life - one's dependence on the land on a daily basis, the lack of technology and industrialisation. Aesthetically, one can include in one's imagination and fantasies the total absence of sound when one is listening to the earth without an electric current running through it, or having the sky appear to be just a few feet away with a blanket of stars rather than looking through smog and light pollution at a distant galaxy.

We need more stories and insights, especially those that connect us throughout history and across cultures. For our purposes, we need stories that transcend time, stories that were told in the 1st century and still make sense more than 2000 years later. Even fictional accounts of events and people are based on the truth of human behaviour and feelings. The problem is that those of us existing somewhere between the environments reminiscent of ancient times (rural Africa) and the western world have lost the sense and impact of ages-old narratives. Worse yet, we apply our own conditions and standards on those texts and forget the crises and celebrations out of which they originated. I have said this before, but it cannot be repeated enough: wherever and whenever I travel to the continent of Africa, I am more and more convinced of my initial insight - that Africans have more knowledge from an experiential context about the Ancient Near East than we westerners can possibly hope to accrue - we certainly will not find this kind of knowledge in books (Jackson 2004b:82).

The experiential came to me only because I love to travel and I consider myself to be a better listener than speaker. But, my question still persists - who gets to tell the story? This is an invitation to continue exploring the issue. I would suggest that it is a mandate as one looks at the state of the world today and its xenophobia, to name only one problem! We need to work together on Mwombeki's hermeneutic of resonance and Hook's bonding across boundaries.

\section{Acknowledgements Competing interests}

The author declares that she has no financial or personal relationships which may have inappropriately influenced her in writing this article.

\section{References}

Dube, M., 1998, '“Go Therefore and Make Disciples of All Nations” (Matt 28:19a)', in F. Fernando Segovia \& M.A. Tolbert (eds.), Teaching the Bible: The discourses and politics of biblical pedagogy, Orbis Books, Maryknoll, NY.

Hooks, B., 1994, Teaching to transgress: Education as the practice of freedom, Routledge Press, New York.

Hooks, B., 2003, Teaching community: A pedagogy of hope, Routledge Press, New York.

Hooks, B., 2010, Teaching critical thinking: Practical wisdom, Routledge Press, New York.

Hooks, B., 2013, Writing beyond race: Living theory and practice, Routledge Press, New York.

Horsley, R., Draper, J. \& Foley, J. (eds.), 2006, Performing the Gospel: Orality, memory, and mark, Fortress Press, Minneapolis, MN.

Jackson, G., 2004a, Hippos are vegetarians, right?, SBL Forum, Atlanta, GA.

Jackson, G., 2004b, 'The Jesus Seminar in Africa', in The historical Jesus Goes to church, pp. 81-90, Polebridge Press, Santa Rosa, CA.

Jackson, G., 2004c, 'Rebel soldiers as good Samaritans: New Testament parables in an African context', HTS Theological Studies 60, 239-247. https://doi.org/10.4102/ hts.v60i1/2.519

Jackson, G., 2005, 'Teaching the parables of Jesus from an African context', in M. Roncace \& P. Gray (eds.), Teaching the Bible: Practical strategies for classroom instruction, pp. 300-302, SBL Resources for Biblical Study 49, Atlanta, GA.

Jackson, G., 2008, 'From Hippo to Hippos: Being on the Edge of Smash in Africa', in C.W. Hedrick (ed.), When faith meets reason: Religion scholars reflect on their spiritual journeys, pp. 1-11, Polebridge Press, Santa Rosa, CA.

Jackson, G., 2011, 'Seeing the world through the eyes of Andries van Aarde: Radical inclusivity', HTS Theological Studies 67(1), 11-16. https://doi.org/10.4102/hts. v67i1.872

Jackson, G., 2013a, 'Parable Parallels from Cameroon', Voices from Kumba 4, 238-252.

Jackson, G., 2013b, 'Death, Afterlife, and Ancestors in Africa' with Jean Ntahoturi and Mbengu David Nyiawung in J. Harold Ellens (ed.), Heaven, Hell, and Afterlife: Eternity in Judaism, Christianity, and Islam, vol. 3, pp. 109-134, Praeger.

Jackson, G., 2014, 'The "Complete Gospel" Revisited: Middle East and African Influences', HTS Theological Studies 70(1), Art. \#2760, 1-6. https://doi. org $/ 10.4102 /$ hts.v70i1.2760

Jesus Seminar, 1993, The five Gospels: What did Jesus really say? Macmillan, New York.

Meier, J., 1994, A Marginal Jew: Rethinking the historical Jesus, Vol. Two: Mentor, message, and miracles, Doubleday, New York.

Mwombeki, F., 2001, 'Reading the Bible in Contemporary Africa', Word \& World 21/2, 121-128, viewed n.d., from http://www.malawiproject.org/about-malawi/ geography/districts-cities-villages/villages 